\title{
Ḥāl (theory of "states" in theology)
}

\author{
Jan Thiele
}

The term $\underline{h a} \mathbf{a} l$ ("state," pl. ahwwāl) was introduced into kalām (rationalist theology) by the Mu'tazilī Abū Hāshim al- Jubbā̄ì (d. 321/933). Modern scholarship has proposed various interpretations of its meaning and function. Ahmed Alami suggested that the concept of hāal was an element of a new ontology that broke radically with the conception of God as absoutely transcendent. There is, however, a broader scholarly consensus that the theory of $h \bar{a} l$ was an attempt to resolve the theological problem posed by God's multiple attributes.

\section{The theory of $h \bar{a} l$ in Mu'tazili theology}

The concept of $h \bar{a} l$ was introduced to answer the question how God can be described by several attributes without violating the monotheistic idea that $\mathrm{He}$ is one and free from multiplicity of any kind. To resolve this logical quandary, it was necessary to explain the meanings of such predications as "God knows," "God lives," and "God is powerful." For most Mu'tazilīs, two solutions that would seem to have been the most obvious were, in fact, fundamentally problematic: affirming that God has such attributes as eternal knowledge and life was interpreted by them as postulating the existence of something co-eternal with God; on the other hand, they believed that positing that God is knowledge, or life, for instance, would undermine His transcendence and make nonsense of the distinction between the various epithets that are found in Qurānic descriptions of God.

Abū Hāshim's later solution of the problem of attributes arose out of intensive debates amongst several generations of scholars. A major step in the discussion had been taken, about a century earlier, by the Mu'tazili theologian al-Nazzāam (d. between 220/835 and 23o/845). He suggested avoiding the positing of any co-eternal entities apart from God and therefore categorically denied that there is something we can rightly call God's knowledge or power. Yet if, according to al-Nazzāam, such predications as "God is knowing" or "God is powerful" do not refer to entities of knowledge and power, he had to analyse these descriptions in a new way. His solution was to argue that God's knowing or creating, for instance, refer to God Himself (ithbāt dhätihi), rather than to entities of knowledge and creation. 
However, later theologians such as the Mu'tazilì Abū 'Alī al-Jubbā'ì (d. 303/915) confronting his argumentation faced new difficulties. For them, the meaning of, for example, "being knowing" is precisely the same whether it is applied to God or to His creation-it denies ignorance in the subject of predication. At the same time, their interpretation relied fundamentally on the assumption that, in the two cases, the predication "he is knowing" reflects different realities: they believed that man, unlike God, knows by virtue of a distinct entity of knowledge and that it is precisely to this entity that the predication "he is knowing" refers.

There was consequently a serious lack of coherence in their analysis of such apparently unambiguous affirmations. In addition — and as a result of the denial of co-eternal attributes - the theory raised problems on a second level. The proponents of actually existing divine attributes referred to these co-eternal entities (e.g., "knowledge") as șifāt (sing. șifa). They could then posit conceptually a descriptive term ("knowing") that expresses linguistically the reality of the entitative attribute. Against these theologians, Abū 'Alī argued that, if the description of God as knowing does not refer to an entity of knowledge, the notion of șifa should be applied to the descriptive term. For him, sifa consequently means a mere act of description (was f ) and does not, in itself, reflect an extralinguistic reality: expressions such as "knowing" and "living" may affirm either the reality of God Himself or of entities of, for instance, knowledge or life that subsist in a body. This, however, imposed strong restrictions on the whole analytical framework: the actual reality expressed by our predications about beings cannot be understood independently from their ontological ground. As a result, it was impossible to conceive of, or even talk about, the qualities of beings as such.

It was Abū 'Alī's son Abū Hāshim who offered an ontological interpretation of attributes that was eventually considered by most Mu'tazilīs to be coherent with their metaphysics. Abū Hāshim's approach consisted in overcoming an ontology that describes whatever we conceive of as either "existent" or "non-existent." Relying on a concept developed by grammarians of Arabic, Abū Hāshim added a new ontological category of so-called "states" (ậwāl). His understanding of a "state" was apparently informed by the Bașran grammarians' analysis of the verb kāna ("to be"). They assumed that the predicate in such sentences as "Zayd was knowing" (kāna Zayd 'äliman) must not be understood as equivalent to the subject of predication; rather, it means that Zayd is (or exists) and that his being is further qualified by a circumstance or manner of being, that is, the "state" of being knowing. Abū Hāshim applied this analysis to the properties we attribute to beings and accordingly conceived of them as "states." According to his understanding and opposed to that of his father, Abū 'Alī, attributes consequently have a reality; unlike entities or things (such as the subjects of our predications), "states" are, however, not real because they actually exist (wujida, yüjadu), but rather their reality—or their becoming actual—is called thubūt (or referred to by the verb thabata, yathbutu, "to be actual/real"). Abū Hāshim's theory consequently offered a solution to two major problems that could not be resolved (or could be resolved only unsatisfactorily) by his Mu'tazilī predecessors: first, his affirmation of the reality 
of "states" allowed him to comprehend God's eternal attributes as something distinct from Him and, in general, to conceive of attributes as such; second, the distinct reality of God's eternal attributes did not violate the notion of monotheism.

Because Abū Hāshim considered only things or entities (ashyā'/dhawāt) knowable ( malüm), he believed that "states" as non-entities cannot be objects of knowledge. Whenever we affirm that somebody is living, the object of our knowledge is the subject referred to as "being living." This allowed for a univocal understanding of two subjects' "being living," irrespective of whether or not the ontological basis for their being alive is the same. Abū Hāshim consequently assumed that we become aware of an object being qualified by a property before we can even explain why it is qualified by this property.

As a result, our understanding of why a specific attribute becomes actual was deferred to a second level of analysis. While Abū Hāshim and his followers affirmed that "being living" has the same meaning when applied to God and to His creatures, they did not claim that, for this reason, God and man are in any way alike: God is necessarily living, and man's attribute of life is only possible. Necessity and possibility were regarded as two modalities (kayfiyyāt) by which attributes become actual, and these modalities now served as a scheme for subclassifying attributes. Several taxonomies of attributes can be found in the Mu'tazilì literature; the overall principle of classification is the same, but some details vary.

One of these categories, called al-șifa al-dhātiyya, șifat al-dhāt, or al-șifa al-nafsiyya, describes what something is in itself, as in such predications as "the black is black" (i.e., it is not white). In modern studies, it is commonly referred to as the "attribute of the essence." All things are necessarily described by an "attribute of the essence," irrespective of whether or not they exist.

The full implications of Abū Hāshim's theory of "states" for the solution of the problem of attributes become apparent with another category of attributes. Abū Hāshim's conception of the $h \bar{a} l$ as being "real" (thābit) allowed him to explain the foundation of specific properties without positing any additional entity: he could simply argue that one $h \bar{a} l$ is grounded in another. Abū Hāshim and his followers believed that this principle can be observed in the created world. In their atomistic world view, all material bodies consist of atoms, and they argued that the atom's very being (kawnuhu jawharan) — that is, its "essential attribute" —necessarily implies (yaqtadī) that the atom occupies space whenever it exists. The same principle of correlation was then applied to God's "essential attribute" and His eternal attributes, that is, His being knowing, powerful, living, and existent (kawnuhu 'āliman, qādiran, hayyan, mawjūdan). The reasoning behind this, for Abū Hāshim and his followers, was that God is eternally qualified by these properties because he is God.

The theologians supposed that several properties of beings cannot be grounded in the qualified subjects themselves - neither directly, as in the case of "essential attributes," nor indirectly, as in the case of attributes grounded in the "essential attributes" of beings. Their most illustra- 
tive example was the existence of the created world. "Being existent" was conceived by Abū Hāshim and his followers as an attribute or hạl. Because the existence of created beings is only possible, they argued that this hâal can be grounded only in some entity distinct from the qualified subject. They concluded that the existence of created beings belongs to a separate category of attributes, namely, those caused by autonomous agents (bi-l-fācil). The reasoning behind this was that only agents, which include God and man, are effective in such a way that they do not necessarily make things happen: they can, on the contrary, refrain from acting, so their possible effectiveness could be logically related to the possible existence of created beings.

A further category was assigned to such changing qualities of beings as motion and rest, or colours. Considering that bodies are not necessarily moving or resting and do not necessarily possess a specific colour, theologians reasoned that these properties are not caused by the bodies themselves. Rather, they believed them to be grounded in something else, namely accidents $\left(a^{\prime} r \bar{a} d\right)$, inherent in the bodies. Accidents as determinants of properties were called also $m a^{\prime} n \bar{a}$ or 'illa, and the category of attributes caused by accidents was therefore denoted șifät ma'nawiyya, șifāt li-ma'nā, or șifät li-illa.

Finally, some sources mention a category of attributes that is grounded neither in the qualified object nor in another entity (lā lil-nafs wa-lā li-mána $)$. In principle, these attributes are similar to the aforementioned attributes that are grounded in other attributes: the only difference is that they are not caused by "the attribute of the essence" but by some other attribute: it is in this sense that la lil-nafs ("not by itself") must be understood. The most frequent example for this category is perception: Abū Hāshim and his followers argued that all living beings without physical defects are perceiving whenever an object of perception exists and so concluded that the attribute of being living causes perception. Authors of later classifications of attributes increasingly saw no reason to distinguish whether an attribute is caused by the "attribute of the essence" or by some other attribute and therefore often omitted completely this fifth category.

\section{The theory of $h \bar{a} l$ in Ash'arī theology}

The concept of ḥāl was at first categorically rejected by Ash'arī theologians. Al-Ash`arī (d. 324/935-6) himself posited that God has co-eternal knowledge, will, and so forth (lahu ilm, irā $d a$, etc.), and that these entities are neither identical with nor other than Him. Therefore, his interpretation of such predications as "God is knowing" differed significantly from that of his Mu'tazilì detractors: for al-Ash'arī, it means that God possesses an entity of knowledge that subsists in Him. As opposed to Abū Hāshim al-Jubbā̄ì, his contemporary, al-Ash'arī denied that the description "being knowing" expresses something distinct from the existence of an entity of knowledge and consequently rejected the notion of "states."

However, Abū Bakr al-Bāqillānī (d. 403/1013), a major representative of Ash'arī theology, adopted the notion of $h a \bar{a} l$ only two generations after the school's founder. Al-Bāqillānī's ap- 
proval of the concept was, in fact, a revision of his early position: in accordance with al-Ash'arī, he still refuted the theory of hāl in his Kitāb al-tamhìd ("The introduction"). Yet, in his later magnum opus in theology, the Hidāyat al-mustarshidīn ("Guide for those seeking right guidance"), he overturned his conviction and argued in favour of the theory of $h \bar{a} l$.

Al-Bāqillānī apparently felt that the original Ash'arī proof for God's entitative knowledge, power, and other attributes was, in some respect, incoherent. Al-Ash'arì's central argument for his position was to postulate that such expressions as "he is knowing" always express the same meaning or truth (haqiqa): if we posit that man is knowing by virtue of an entity (ma'nā) of knowledge, the same must be true of God. In response, al-Bāqillānī argued that al-Ash'arī's claim presupposes a correlation (ta'alluq) between that which is expressed by "being knowing" and the entity of knowledge - more precisely, a reciprocal correlation: whenever we describe someone as knowing, it is evidence for an entity of knowledge that subsists in the subject; and, vice versa, the entity of knowledge is the cause for the subject's "being knowing." Al-Bāqillānī now objects that, if "being knowing" referred merely to the entity of knowledge and not to a reality distinct from this entity, one would attempt to prove the existence of divine knowledge by itself. This, however, would be circular reasoning. Al-Bāqillānī concludes that such predications as "being knowing" refer to a $h \bar{a} l$, which is grounded in and evidence for the existence of an entity of knowledge. He relied on the concept to prove the existence of entitative attributes in God that, like Him, are eternal.

Al-Bāqillānī shared the Mu'tazilī view that the hạal cannot be described as existent or nonexistent. Nonetheless_-and against Abū Hāshim al-Jubbā'̄ - he believed that a hă $\bar{a}$ must be knowable, even though it is not an entity or thing (dhāt). In the Ash'arī context, the hâal is frequently denoted $h u k m$. This trend is also evident in the writings of Abū l-Maālì al-Juwaynī (d. 478/1085-6), who followed al-Bāqillānì in adopting the concept of hạal in the framework of his theory of attributes.

The adoption of the theory of hăl remained controversial amongst Ash'arī theologians and was debated in the sources. In one of these discussions, Sayf al-Dīn al-Āmidī (d. 631/1234) reported that, like Mu'tazilīs and Ash'arīs, some Karrāmī theologians also adopted the theory, although he provided no further details.

\section{Bibliography}

Ahmed Alami, L'ontologie modale. Étude de la théorie des modes d'Abū Hāšim al-Ğubbā̄̄u, Paris 2001.

Fedor Benevich, The classical Ash`ari theory of aḥwāl. Juwaynī and his opponents, JIS 27 (2016), 136-75.

Richard M. Frank, Al-aḥkām in classical Ašcarite teaching, in R. Morelon and A. Hasnawi (eds.), 
De Zénon d'Élée à Poincaré. Receuil d'études en hommage à Roshdi Rashed (Leuven 2004), $753-77$.

Richard M. Frank, Beings and their attributes. The teaching of the Basrian school of the Mu'tazila in the classical period, Albany 1978.

Richard M. Frank, Ḥāl, EI2 Suppl.

Daniel Gimaret, La théorie des aḥwâl d'Abû Hâšim al-Ǧubbầî d'après des sources ašarites, JA 258 (1970), 47-86.

Jan Thiele, Abū Hāshim al-Jubbā'ī's (d. 321/933) theory of "states" (aḥwāl) and its adaption by Ash'arite theologians, in Sabine Schmidtke (ed.), The Oxford handbook of Islamic theology (Oxford 2016), 364-83.

Jan Thiele, Theologie in der jemenitischen Zaydiyya. Die naturphilosophischen Überlegungen des al-Hasan ar-Rașșās, Leiden 2013.

Aron Zysow, Karrāmiya, EIr.

The research leading to these results has received funding from the People Programme (Marie Curie Actions) of the European Union's Seventh Framework Programme ( $\left.\mathrm{FP}_{7} / 2007-2013\right)$ under REA grant agreement no 624808. 